
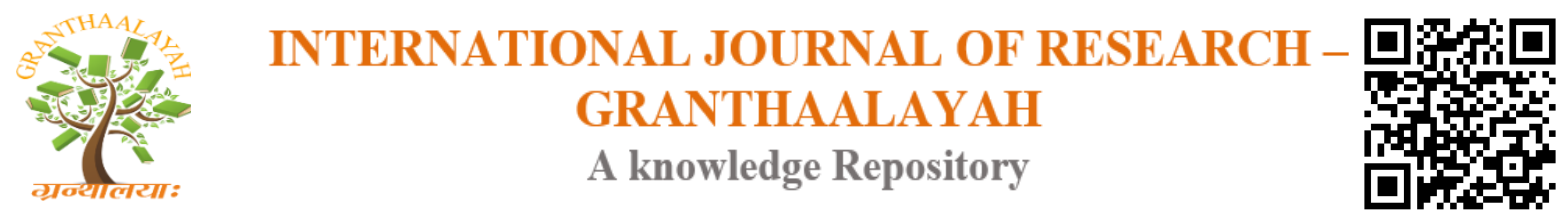

Management

\title{
DETERMINANTS OF URBAN YOUTH UNEMPLOYMENT: THE CASE OF GUDER TOWN, WESTERN SHOA ZONE, ETHIOPIA
}

\author{
Amenu Leta Duguma *1, Fufa Tesfaye Tolcha ${ }^{2}$ \\ ${ }^{* 1,2}$ Department of Agricultural Economics, College of Agriculture and Veterinary Science, \\ Ambo University, Ethiopia
}

\begin{abstract}
Despite numerous interventions by government and development partners, youth unemployment has remained an intractable challenge in Ethiopia. It creates many social- economic problems in the economy of the country. This study however aimed to identifying the determinants of urban youth unemployment. The study adopted a cross sectional data of urban youth employmentunemployment. The town was purposively selected from the town of west shoa zones. The primary data was collected from 91 sample respondents through interview questionnaire from Guder town proportionally. A descriptive and econometric analysis was employed to meet the main objective of the study. The descriptive analyses results revealed that about $61.5 \%$ of the youth are unemployed while $38.6 \%$ are employed. Regression results from a binary logit model estimation show that sex, educational level, marital status, skill match and access to credit use of youth are found to be the significant determinants to urban youth unemployment while family prosperity and market information were statistically insignificant to urban youth unemployment in the town. The econometric results suggested the need for the government go aboard on creating jobs through identify employment opportunities and industrialization of agriculture. It also recommended that the government should facilitate formalization of familiar employment which reduces the problem of youth unemployment especially on skilled and educated youth and all secondary schools should have active partnership with employers. As well as government made to increase the availability of initial working capital, the identification of profitable (market gap) business areas and provision of practical training for urban youths to be engaged at their own business.
\end{abstract}

Keywords: Unemployment; Determinants; Binary Logit Model; Youth.

Cite This Article: Amenu Leta Duguma, and Fufa Tesfaye Tolcha. (2019). "DETERMINANTS OF URBAN YOUTH UNEMPLOYMENT: THE CASE OF GUDER TOWN, WESTERN SHOA ZONE, ETHIOPIA." International Journal of Research - Granthaalayah, 7(8), 318-327. https://doi.org/10.29121/granthaalayah.v7.i8.2019.674.

\section{Introduction}

Unemployment is the most challenging economic problem facing the government. It is a vital challenge for both developed and developing world (Kabaklalri et al, 2011). The ability of youth 
to engage in productive activities has both social and economic consequences for an economy. In developing countries, youth face not only the challenge of obtaining productive employment, but also obtaining safe and acceptable work. According to Organization for Economic Co-operation and Development (OECD. 2010) estimates, there are 85 million unemployed youth around the world.

Unemployment is the condition which is characterized with the incapability of an individual to find a job of any kind. According to ILO (2012) defines unemployment is the main challenges of the modern era in both the developed and developing countries, especially youths, which the United Nations defines as, those between the ages of 15-24, are more affected by unemployment. Young people are more vulnerable to lack experience, social networks or other qualifications that would make them difficult to find employment. In most regions youth were nearly three times more likely to be unemployed than adults (Amanuel D. 2016).

The labor force is growing with an increasing proportion of youth and employment growth is inadequate to absorb this high proportion of labor force specially the youth part in different sectors of the economy in Ethiopia (Alemnew, 2014: cited at Aynalem Sh. and Mulugeta D. (2018). The country is the highest urban unemployment rates worldwide, at about $50 \%$ of the youth labor force (Berhanu et al., 2005).

Despite the recent economic growth witnessed in Ethiopia, youth unemployment is high and rising (Martha, 2012). The problem is more severe in urban than in rural area. According to Ethiopian labor force survey report, the unemployment rate of urban youth at country level was 22.9 while it was only 3.1\% in rural areas Labor Force Survey (LFS), 2013). It is special concern for Ethiopians and has a wider implication for the youth in addition to leading their life as expected to help parents and extended families (Shumet, 2011). According to a survey in 55 urban areas, unemployment was estimated at $41.3 \%$ and the incidence of youth unemployment was $45.5 \%$ and $35.7 \%$ for females and males respectively (Alemnew, 2014: cited in Aynalem Sh. and Mulugeta D. 2018).

As different studies indicated unemployment is a global issue that challenging every nation. It represents the underutilization of human capital and it is very important issue that negatively affects the development of the country. The potential causes of unemployment in urban Ethiopia include increasing number of youth labor force, the rising internal migration, literacy rate, poor to modest macroeconomic performance, low level of job creation and low level of aggregate demand in the economy (Getinet, 2003; WB, 2007). Youth unemployment is the outcome of different socio-economic factors at macro and micro level (Toit, 2003: cited in Aynalem Sh. and Mulugeta D. 2018).

One of the dominant social and economic problems facing our world, youth unemployment prompted several enquiries.

Studies by Pieter (2008) and Nye (2012) focus on the labor side analysis aiming for a demand base analysis on the issue. Asalfew (2011) and Tsegay, IGC (2012) intended to measure the magnitude and the determinants of the problem. The subject of unemployment is further scrutinized form several angles in an effort to address the daring challenge of youth joblessness. 
Martha (2012) concluded that unemployment (mainly as an urban phenomenon) and underemployment continued to be serious social problems in Ethiopia despite some improvements in recent years. The problem of youth unemployment is growing rapidly in Ethiopia particularly in Guder town and unemployment results social exclusion and a sense of hopelessness on youth. This calls for a careful study of the determinants of urban youth unemployment.

Identifying the determinant factors influencing urban unemployment of youth residents should be the first step to come up with the alternative strategies to resolve the problem, even though few studies were conducted on the determinants of urban youth unemployment (Alemnew, 2014: cited in Aynalem Sh. and Mulugeta D. (2018), the results of these studies are varied depending on the specific socio-economic situation of the study area. Therefore, this study is aimed to understand the determinants and characteristic of urban youth unemployment at Guder town dwelling using the binary logistic regression model.

\section{Materials and Methods}

\subsection{Study Area}

The study was conducted at Guder town which is located in Oromia Regional State West Shoa Zone. It bounded by Chaliya Woreda in West, Ambo Woreda in the East, Mida kegn Woreda in North, and Tikur Inchini Woreda in South. This town has latitude and longitude 89667(8'58 N) and 377667 (37'46 E) respectively, with an elevation of 2101 meter above sea level. The town is located at 136 kilometer from capital of Addis Ababa. The town has an estimated total population of 12569 with total youth population of 1038 from two kebeles namely 01and 02 kebele Central Statically Agency (2013).

\subsection{Sampling Techniques and Research Design}

A cross sectional survey design was used to collect data from the respondents. Purposive sampling techniques were employed to select Guder town considering numbers of urban dwellers living there. This study is conducted at individual level, the required number of sample drawn is the total number of active labor force of youth was purposively selected from the sampling frame or the total population found in the towns. Both primary data and secondary data were collected from youth's representative respondents and different sources. The data was collected from selected respondents in the study area through interview questionnaire and key informant's discussion.

\subsection{Sample Size Determination}

To determine the representative sample size from the town, the study used a sample size determination formula given by Yamane (1967)

$n=\frac{N}{1+N(e)^{2}} \quad n=\frac{1038}{1+1038(0.1)^{2}}=91$

Where: $\mathbf{n}$ is the representative sample size, $\mathbf{N}$ is the total youth population of the towns which is found to be the total 1038 Central Statically Agency (2013) and $\mathbf{e}=$ is level of precision defined 
to determine the required sample size at $95 \%$ confidence level. A total of 41 and 50 youths are from 01 and 02 kebeles town respectively.

\subsection{Method of Data Analysis}

Descriptive and econometric analyses were employed to meet the objective of the study. In the case of descriptive analysis tables, average and percent were employed, while the econometric analysis binary logit model was employed to identify determinants of urban youth unemployment.

\subsection{Model Specification}

Unemployment status of urban youths: dependent variable of the model that is dichotomies or dummy variable that take value $0=$ if urban youth is employed and $1=$ if urban youth is unemployed. The appropriate econometric technique deal with such type of data is using binary logit and probit models and the most popular statistical techniques was used to analysis the probability of a dichotomous outcome (such as employed or unemployed) with a set of explanatory variables. Binary logistic regression model was used to identify determinants of urban youth unemployment. It is a special type of logistic regression model which is used to describe the relationship between one or more independent variables and a binary outcome variable that has only two possible values. Logistic regression is used in a wide range of applications leading to categorical dependent data analysis (Agresti, 2002).

Gujarati (2004) the logistic model could be written in terms of the odds ratio and log of odds ratio, which enable one to understand the interpretation of the coefficients. In this study, the odds ratio is the ratio of the probability that the youth will be unemployed $(\mathrm{Pi})$ to the probability that he/she will be employed (1-Pi).

$$
\begin{aligned}
p i & =f(Z i)=f(\alpha+\beta i \chi i) \\
& =\frac{1}{1+1 e^{-(\alpha+\Delta \beta i \chi i)}}
\end{aligned}
$$

Since, $Z \mathrm{i}=\alpha+\beta i \chi i$ the above formula can be rewrite as shown below for easily understanding.

$$
\begin{aligned}
& (1-p i)=\frac{1}{1+e^{Z i}} \\
& \left(\frac{p i}{1-p i}\right)=\frac{1+e^{Z i}}{1+e^{-Z i}}=e^{Z i}
\end{aligned}
$$

Therefore, $\left(\frac{p i}{1-p i}\right)=\frac{1+e^{Z i}}{1+e^{-Z i}}=e^{(\alpha+\Delta \beta i+\chi i)}$ 
Taking the natural logarithm from above equation

$$
y i=\ln \left(\frac{p i}{1-p i}\right)=\alpha+\sum_{i=1}^{K} \beta i \chi i+\varepsilon i
$$

Where

$\mathrm{K}=$ Number of independent variable included into the model

$\chi i=$ Vector of independent variable

$\varepsilon i=$ Error term (disturbance term)

$\alpha=$ value of $\log$ oddratio $\frac{(p i)}{1-p i)}$ When $\mathrm{Xi}$ or independent variable is zero

$\beta=$ Measures the change in $\mathrm{L}$ (logit) for a unit change in explanatory variables (X)

$\gamma i=$ Dependent variable that take value $\mathrm{y}=\mathrm{o}$ if youth is employed and $\mathrm{y}=1$ if youth unemployed

Table1: Summary of independent variables that may influence urban youth unemployment

\begin{tabular}{|l|l|l|c|}
\hline Variable code & Description & Categorical & Expected sign \\
\hline EMPS & Employment Status & $\begin{array}{l}0=\text { Employed } \\
1=\text { Unemployed }\end{array}$ & \\
\hline SEX & Sex & $0=$ Female, $1=$ Male & $+/-$ \\
\hline MART & Marital status & $0=$ Married, $1=$ unmarried & + \\
\hline EDUL & Educational level & $\begin{array}{l}0=\text { Illiterate } \\
1=\text { Primary school } \\
2=\text { Secondary school } \\
3=\text { Certificate \&above }\end{array}$ & + \\
\hline ACCRU & Access to credit use & $\begin{array}{l}0=\text { No access to credit use } \\
1=\text { Access to credit use }\end{array}$ & $+/-$ \\
\hline ACCMI & Access to market information & $\begin{array}{l}0=\text { Sometime } \\
1=\text { Always }\end{array}$ & $+/-$ \\
\hline SKILL & Skill match & $0=$ Match,1= mismatch & + \\
\hline FPL & Family prosperity level & $0=$ Rich, $1=$ poor & $+/-$ \\
\hline
\end{tabular}

\section{Results and Discussions}

\subsection{Features of Urban Youth Unemployment}

Youth unemployment by gender: The majority of the respondents are male in their sex. Of the total responses, 65.9 percent are male and 34 percent are female with average year of the sample is 24.5 years. The highest unemployment is seen for male youth 40(43.9 percent) respondents but 16(17.5 percent) respondents' female youth. Using those male respondents as a base, the analysis shows that those who are female respondents have a low level unemployment rate as compared to male youth in the study area.

\section{Youth Unemployment by Educational Status}

The association between education and employment condition is crucial. It is known that education is a very important for innovation, job creation and poverty alleviation. The unemployment rate 
for illiterate, primary school, secondary school, and certificate \& above graduate youth are $4.4 \%$, $6.6 \%, 14.3 \%$ and $36.3 \%$ respectively in the study area. In line with this, table 2 shows that youth who have certificate and above education level has low opportunity in obtaining jobs in the study area.

Youth unemployment by Marital status: relatively larger proportion, 53.8 percent of the youth are never married while about 46 percent of them are married with average household size is 3.2 family members. The highest unemployment rate is seen for unmarried youth 39(42.8\%) of respondents but $17(18.7 \%)$ of respondents' married followed by live together. Using those unmarried as a base, the analysis shows that those who had married youth have a low level unemployment rate as compared to unmarried in the study area.

\section{Youth Unemployment by Work Condition of Employed Youths}

As regard to those employed, 10(28.5 percent) is self employed followed by private, government sector employees and unpaid family worker, 13(37\%), 7(0.2\%) and 5(14.3\%) respectively. It is good to see the highest proportion is private organization and self employed; otherwise it is difficult for the government to provide job for all unemployed youths.

Youth unemployment by Match skill: measured with relative to mismatch and matched. From the sample respondents the unemployment youth for those skills are matched was 36(64.3\%) while for those mismatch was $20(35.7 \%)$ and the respondents youth employed for those whose skills are mismatch 5 and matched was 30 respectively.

\section{Youth Unemployment by Family Prosperity Level}

measured with relative to rich and poor based on the living condition of the society at the study area. The result revealed that the unemployment rate of individuals from poor families was $38(67.8 \%)$ while for individuals from rich families was $18(32.1 \%)$ respectively.

\section{Youth Unemployment by Access to Market Information}

shows that the proportion of employment status of youth varies significantly with access to market information with regard to this, the higher 39(69.6\%) of the unemployed youths always access to market information.

\section{Youth Unemployment by Access to Credit Use}

survey results show that the proportion of employment status of youth varies significantly with access to credit use with regard to this, the higher 38(67.8\%) of the unemployed youths was from no access to credit use.

\section{Youth Unemployment by Employment Status}

Based on the collected data the majorities 56(61.5 percent) of the respondents are unemployed and the remaining 35(38.6 percent) respondents are employed in the study area under different working conditions. 
Table: 2: Urban youth labor market characteristics by sex, education level, marital status, and access to credit use, access to market information, working condition, skill match and Family prosperity level.

\begin{tabular}{|c|c|c|c|c|}
\hline \multirow{3}{*}{ Variable } & \multicolumn{4}{|c|}{ Unemployment Status } \\
\hline & \multicolumn{2}{|c|}{ Employed } & \multicolumn{2}{|c|}{ Unemployed } \\
\hline & Number & Percent & Number & Percent \\
\hline Employment status & 35 & 38.6 & 56 & 61.5 \\
\hline \multicolumn{5}{|l|}{ Sex of the youth } \\
\hline Female & 15 & 16.5 & 16 & 17.5 \\
\hline Male & 20 & 21.9 & 40 & 43.9 \\
\hline \multicolumn{5}{|l|}{ Youth Educational level } \\
\hline Illiterate & 9 & 9.9 & 4 & 4.4 \\
\hline Primary education & 3 & 3.3 & 6 & 6.6 \\
\hline Secondary education & 5 & 5.5 & 13 & 14.3 \\
\hline Certificate graduate \& above & 18 & 19.8 & 33 & 36.3 \\
\hline \multicolumn{5}{|l|}{ Marital status } \\
\hline Married & 25 & 27.5 & 17 & 18.7 \\
\hline Unmarried & 10 & 10.9 & 39 & 42.8 \\
\hline \multicolumn{5}{|l|}{ Access to credit use } \\
\hline Access to credit use & 24 & 68.5 & 18 & 32 \\
\hline No access to credit use & 11 & 31.4 & 38 & 67.8 \\
\hline \multicolumn{5}{|l|}{ Access to market information } \\
\hline Some times & 26 & 74.3 & 17 & 30.4 \\
\hline Always & 9 & 25.7 & 39 & 69.6 \\
\hline \multicolumn{5}{|l|}{ Work condition employed youth } \\
\hline Government employed & 7 & 0.2 & - & - \\
\hline Private employed & 13 & 37 & - & - \\
\hline Self Employed & 10 & 28.5 & - & - \\
\hline Unpaid Family Worker & 5 & 14.5 & - & - \\
\hline \multicolumn{5}{|l|}{ Skill match } \\
\hline Mismatch & 5 & 14.2 & 20 & 35.7 \\
\hline Match & 30 & 85.7 & 36 & 64.3 \\
\hline \multicolumn{5}{|l|}{ Family prosperity level } \\
\hline Poor & 19 & 54.3 & 38 & 67.8 \\
\hline Rich & 16 & 45.7 & 18 & 32.1 \\
\hline
\end{tabular}

\subsection{Determinants of Urban Youth Unemployment}

Binary logit model was selected to identify the determinants of urban youth unemployment in the study area. Before fitting the model, it was important to check existence of multi collinearity problem among explanatory variables. Variance inflated factors (VIF) was used to test existences of multi collinearity problem among variables. The calculated value of VIF was below 10, there is no serious multicollinearity problem among the explanatory variables. A total of 7 variables included into the model that may affect urban youth unemployment were considered. Among them 5 of the variables (Sex, educational level, marital status, skill match and access to credit use) 
were found significant while the rest two variables (family prosperity and market information) were statistically insignificant to urban youth unemployment.

\subsubsection{Interpretation and Discussion of Significant Model Out Come}

Sex of youth: positive and significantly affect employment status of youth in the study area. The results show those males are $71.99 \%$ more likely to unemployed as compared to female youth. The study contradicts with the finding of Amanu'el D., (2016).

Educational level of youth: Education level has shown positive relationship with employment status of youth. The result reveals that as education level of respondents' increases from primary school up to certificate graduate the level of youth unemployment increased. It is found that youths who attend certificate graduate and higher education were more likely to be unemployed. The odds ratio of being unemployed increases by 23.7 percent if the individual attended certificate graduate and above compared to those who are illiterate another justification for why unemployment rates tend to be higher among the more educated young is that there is unavailability of resources to support full-time job search.

Skill Match: The matches between the non-match skill acquired and demanded for labor market have a positive effect on youth unemployment. The result reveals that non skill match and unemployment are positively correlated. As non-match skill demand is increases, the odds ratio of being unemployed will increase by 53.8 percent if the individual's skill and the demand by the market becomes non match. This result is contradicts with the study of (Alemnew, 2014: cited in Aynalem Sh. and Mulugeta D. (2018).

Marital Status: There is a positive association between getting unmarried and being unemployed. The Logit model predicts that if youths are unmarried their unemployment status increases by the odds ratio of 33.5 percent compared to married. This is true if unmarried youth not it give more attention for work to improve his livelihood as compared to married youth. This is contradicts with the finding by (Krishnan 1996: cited in Aynalem Sh. and Mulugeta D. (2018).

Access to Credit Use: Availability of credit use is positive correlated with youth unemployment. The Logit model predicts that if youths are lack of credit use their unemployment status increases by the odds ratio of 82.5 percent compared to credit use. This is contradicts with the finding by Aynalem Sh. and Mulugeta D. (2018).

Table 3: Logistic Regression Model result of Determinants of youth unemployment

\begin{tabular}{|c|l|l|l|l|}
\hline Variable & Coefficient & Odd ratio & Std. Err. & P-value \\
\hline Constant & 0.526 & 0.125 & 1.486 & 0.723 \\
\hline Sex of youth & -0.238 & 0.262 & 0.465 & 0.609 \\
\hline Female & 0.345 & 0.7199 & 6.608 & $0.032^{*}$ \\
\hline Male & \multicolumn{5}{l}{} \\
\hline Education level & 0.425 & 0.0407 & 0.473 & 0.369 \\
\hline Illiterate & 0.525 & 1.135 & 0.492 & 0.287 \\
\hline Primary school & 0.575 & 0.727 & 0.673 & 0.393 \\
\hline Secondary school & 5.537 & 23.733 & 1.137 & $0.000^{*}$ \\
\hline Certificate and above & \multicolumn{3}{l}{} \\
\hline Marital status & 0.039 & 0.006 & 0.521 & 0.940 \\
\hline Married & 0.395 & 0.335 & 0.2103 & $0.081^{*}$ \\
\hline Unmarried
\end{tabular}




\begin{tabular}{|c|l|l|l|l|}
\hline Available skill match \\
\hline Match & 0.399 & 0.591 & 0.519 & 0.442 \\
\hline Non match & 0.764 & 5.385 & 4.821 & $0.060^{*}$ \\
\hline Family prosperity level & 0.659 & 2.026 & 0.463 & 0.155 \\
\hline Poor & 0.306 & 0.363 & 0.507 & 0.547 \\
\hline Rich & -0.707 & 1.886 & 0.515 & 0.170 \\
\hline Access to credit use & 1.605 & 8.254 & 0.559 & $0.004^{*}$ \\
\hline Available credit use & & & \\
\hline No availability of credit use & \multicolumn{5}{l}{} \\
\hline Access to market information & 0.343 & 0.163 & 0.852 & 0.687 \\
\hline Some time & -5.637 & 24.523 & 1.138 & 0.456 \\
\hline Always
\end{tabular}

\section{Conclusions and Recommendations}

In conclusion, this research work aimed to identify determinants of urban youth unemployment in Guder town. The studies were employed Binary logit regression model. In the model unemployment status of urban youth were taken as dependent variable and seven explanatory variables were included. The result of the binary logit models, show that five of the explanatory variables were found significant determinant to urban youth unemployment; of which, Sex, educational level, marital status, skill match and access to credit use. The study found that certificate graduate and above becomes more exposed to unemployed. Therefore, the government and concerned bodies should review job market regulation to enhance educated youths to be employed which can help them to contribute their role for their country. Moreover, emphasis should be given when new education programs are opened; a detailed study is required to make match between the demand and supply of education since match between individuals acquired skill and knowledge with the market demand factors of unemployment. It revealed that youth which have no access to credit use were more unemployed. Thus, intervention is required to financing youth through participating all private investor and government offices. Moreover, the study recommended that the concerned bodies should try to create suitable environment condition through identify employment opportunities. Final the government should facilitate formalization of familiar employment sector to motivate more youth to engage in different activities which reduce the problem of youth unemployment especially on skilled and educated youth in urban areas and efforts should be made to increase the availability of initial working capital, the identification of profitable (market gap) business areas and provision of practical training for urban youths to be engaged at their own business.

\section{References}

[1] Agresti A., (2002). Categorical Data Analysis. Wiley Inter science, New York.

[2] Alemnew Getnet (2014). Socio-economic \& Demographic Determinants of Graduate youths' unemployment: In the case of Debre Markos town, Amhara Regional State, University of Gonder.

[3] Amanu'el Disassa (2016). Determinants of youth Unemployment; Evidence from Ethiopia, Global Journal of Human-Social Science. Arts \& Humanities - Psychology Volume 16, ISSN: 2249460x \& Print ISSN: 0975-587X.

[4] Asalfew Abera (2011). Demographic and Socio-Economic Determinants of Youth 
[5] Aynalem SH. and Mulugeta D. (2018). Determinants of urban youth unemployment in East Gojjam Zone of Amhara Region, Ethiopia. International Journal of Economic Development Volume11, Number 2 pp. 245-265.

[6] Berhanu, D., Abraham T. \& Hannah D., (2005). Characteristics and Determinants of Youth Unemployment, Underemployment and Inadequate Employment in Ethiopia

[7] Central Statistically Agency (2013). Statistical Report on National Labour Force Survey. Addis Ababa, Ethiopia. Evidence from urban Ethiopia, University of East Anglia. Contact: p.serneels@uea.ac.uk

[8] Getinet Haile, (2003). The Incidence of Youth Unemployment in Urban Ethiopia. Paper presented at the 2nd EAF International Symposium on Contemporary Development Issues in Ethiopia, 11-13 July, Addis Ababa, Ethiopia.

[9] Gujarati N. Damondar, (2004). Basic Econometrics, 4th Edition. The McGraw- Hill Companies.

[10] ILO (2010). Growth-employment-poverty reduction linkages: a framework for recovery and accelerated.

[11] Krishnan, P. (1996). Family Background, Education and Employment in Urban Ethiopia. Oxford Bulletin of Economics and Statistics, 58(1), 167-182.

[12] Labor Force Survey (LFS) (2013). Statistical Report on the 2013. National Labour Force Survey, Central Statistical Agency, Addis Ababa, Ethiopia.

[13] Martha Kibru., (2012). Employment Challenges in Ethiopia. Addis Ababa, Ethiopia

[14] OECD (Organisation for Economic Co-operation and Development). (2010). Reducing the involvement of youth in armed

[15] Pieter S. (2008). Unemployment duration, job search and labor market segmentation

[16] Shumet, G. (2011). A Glimpse of Urban Youth Unemployment in Ethiopia. Ethiopian Journal of Development Research, vol.33, No.2.

[17] Toit, R. (2003). Unemployed Youth in South Africa: The Distressed Generation, Paper presented at the Minnesota International Counseling Institute, Minnesota. Unemployment in Debere birhan town, North Showa administrative zone, Amhara National Regional State. Addis Ababa, Ethiopia

[18] Violence Programming Note. Paris: OECD. https://www.oecd.org/dac/conflict-fragilityresilience/docs/47942093.pdf

[19] World Bank (WB, (2007). Urban labor markets in Ethiopia: Challenges and prospects: The World Bank

[20] Yamane T. (1967). Statistics: An introductory Analysis, 2nd Ed: New York.

\footnotetext{
*Corresponding author.

E-mail address: amenuleta@gmail.com
} 